\title{
Pelkkä seosrehu tai laimeampi seosrehu ja väkirehulisä lypsylehmien ruokinnassa
}

\author{
Hannele Khalili, Päivi Mäntysaari, Juha Sariola, Reima Kangasniemi \\ MTT, kotieläintuotannon tutkimus, 31600 Jokioinen, etunimi.sukunimi@mtt.fi
}

\section{Tiivistelmä}

Maatiloilla on menossa voimakas rakennekehitys, jonka seurauksena muodostetaan suurempia tuotantoyksiköitä. Tilat ja karjakoot kasvavat, jolloin pihatot yleistyvät ja ruokintasysteemit muuttuvat. Suurissa tuotantoyksiköissä pihatto-olosuhteissa seosrehuruokintastrategia on yleisesti valittu ruokintasysteemi, mutta pihatoissa on usein käytössä myös väkirehukioskit.

Tämän tutkimuksen tarkoituksena oli selvittää väkirehukioskin merkitystä seosrehuruokinnan täydentäjänä pihatossa. Tutkimuksessa verrattiin pelkän seosrehuruokinnan sekä ruokinnan, jossa laimeampaa perusseosta täydennetään lypsykauden alussa väkirehuautomaatista saatavalla lisäväkirehuannoksella vaikutusta lypsylehmien syöntiin, maidontuotantoon ja maidonkoostumukseen.

Koe suoritettiin MTT:n Minkiön tutkimuspihattossa Jokioisilla. Koelehmiä oli kaikkiaan 39 Ay lehmää. Puolet koelehmistä (ryhmä S) sai ainoana rehuna seosrehua (seos A), jossa väkirehun osuus kuiva-aineesta oli 51\% ja puolet (ryhmä KS) seosta (seos B), joissa väkirehun osuus oli kuiva-aineesta 45\%. KS-ryhmä sai lisäksi lypsykauden alussa lisäväkirehua kioskista ja annos oli laktaatiopäivinä 1 100 useammin poikineilla $6,5 \mathrm{~kg} / \mathrm{pv}$ ja ensikoilla $5,5 \mathrm{~kg} / \mathrm{pv}$. Laktaatiopäivinä $101-150$ oli lisäväkirehuannos useammin poikineilla $3,0 \mathrm{~kg} / \mathrm{pv}$ ja ensikoilla $2,5 \mathrm{~kg} / \mathrm{pv}$. Loppulypsykaudella (yli 150 päivää poikimisesta) sai KS-ryhmä pelkästään seosta B, lisäväkirehua ei annettu. Seosrehuissa (A ja B) käytettiin samaa nurmisäilörehua ja MTT:llä sekoitettua väkirehua. Väkirehukioskista saatava lisäväkirehu oli teollista täysrehua.

Kokeenaikaisiin keskimääräisiin kuiva-aine syönteihin ja ravintoaineiden saantiin ei kioskilisällä ollut vaikutusta. Ensimmäisen 100 lypsypäivän aikana syönti kehittyi samaa vauhtia niin pelkällä seos kuin seos ja kioskiryhmälläkin. Sen sijaan seuraavan 50 päivän aikana oli syönti seosryhmällä korkeampi $(\mathrm{P}<0.10)$. Ilmeistä on, että kun kioskiannos pudotettiin 100 lypsypäivän jälkeen, niin kioskiryhmän lehmät eivät pystyneet lisäämään seoksen syöntiä vastaavaa määrää ja näin kokonaissyönti jäi alhaisemmaksi. Vastaava notkahdus syönneissä nähdään myös 150 päivän kohdalla kun kioskirehu jätettiin kokonaan pois.

Johtopäätökset: tulokset osoittivat, että väkirehun kokonaiskulutuksessa koekaudella ei ruokintastrategioiden välillä ollut eroa. Ruokintastrategioiden välillä ei ollut eroa myöskään keskimääräisissä tuotoksissa, syönneissä tai kunnon kehityksessä. Kaiken kaikkiaan koetulokset osoittivat, että molemmat ruokintastrategiat soveltuivat hyvin lehmien ruokintaan.

Asiasanat: maidontuotanto, lypsylehmät, ruokinta, seosrehu, väkirehukioski, pihatto 


\section{Johdanto}

Suurissa tuotantoyksiköissä pihatto-olosuhteissa seosrehuruokintastrategia on yleisesti valittu ruokintasysteemi, mutta pihatoissa on usein käytössä myös väkirehukioskit. Aikaisemmissa kotimaisissa seosrehukokeissa on hyvin yksinkertaisella yhden seoksen ruokintamallilla saatu yhtä hyvät tulokset kuin useamman seoksen sekoittamisella (Mäntysaari ym. 2003, Mäntysaari ym. 2004, Mäntysaari ym. 2005). Näissä kaikissa kokeissa ovat koe-eläimet olleet kuitenkin ensikoita. Ensikoiden tarpeet verrattuna täysikasvuisten lehmien tarpeisiin ovat erilaiset. Ensikoiden matalammat tuotokset lypsykauden alussa, mutta suhteellisen tasainen lypsykäyrä ja lisäksi oma kasvu lypsykauden lopussa johtavat siihen että yhden seoksen ruokinta koko lypsykauden on mahdollista.

Useamman kerran poikineilla tuotokset ovat alkulypsykaudesta selvästi korkeammat kuin loppu lypsykaudesta. Tämän vuoksi yhdenseoksen ruokinnalla riittävän väkevän seoksen sekoittaminen alkulypsykaudella oleville lehmille voi johtaa loppulypsykaudella lehmien lihomiseen. Laimeamman perusseoksen väkevöittäminen alkulypsykaudesta kioskista saadulla väkirehuannoksella voi olla ratkaisu mahdolliseen ongelmaan. Näin väkirehukioskeja hyväksikäyttäen voidaan painottaa väkirehunanto lypsykauden alulle ilman että tarvitsisi sekoittaa useampia seoksia.

Tämän tutkimuksen tarkoituksena oli selvittää väkirehukioskin merkitystä seosrehuruokinnan täydentäjänä pihatossa. Tutkimuksessa verrattiin pelkän seosrehuruokinnan sekä ruokinnan, jossa laimeampaa perusseosta täydennetään lypsykauden alussa väkirehuautomaatista saatavalla lisäväkirehuannoksella vaikutusta lypsylehmien syöntiin, maidontuotantoon ja maidonkoostumukseen sekä kuntoluokitukseen.

\section{Aineisto ja menetelmät}

Tutkimus suoritettiin MTT:n Minkiön tutkimuspihattossa Jokioisilla sisäruokintakaudella 2003-2004. Tutkimus toteutettiin jatkuvana kokeena ja lehmät tulivat kokeeseen poikimisen jälkeen. Koelehmiä oli kaikkiaan 39 Ay lehmää, joista 15 oli ensikoita ja 24 useamman kerran poikineita. Puolet koelehmistä (ryhmä S) sai ainoana rehuna seosrehua (seos A), jossa väkirehun osuus kuiva-aineesta oli $51 \%$ ja puolet (ryhmä KS) seosta (seos B), joissa väkirehun osuus oli kuiva-aineesta 45\%. KS-ryhmä sai lisäksi lypsykauden alussa lisäväkirehua kioskista ja annos oli laktaatiopäivinä $1-100$ useammin poikineilla 6,5 kg/pv ja ensikoilla 5,5 kg/pv. Laktaatiopäivinä 101 - 150 oli lisäväkirehuannos useammin poikineilla 3,0 kg/pv ja ensikoilla 2,5 kg/pv. Loppulypsykaudella (yli 150 päivää poikimisesta) sai KS-ryhmä pelkästään seosta B, lisäväkirehu ei annettu (Taulukko 1).

Seosrehuissa (A ja B) käytettiin samaa nurmisäilörehua ja MTT:llä sekoitettua väkirehua. MTT:n väkirehu sisälsi (g/kg) ohraa (606), rypsipuristetta (270), melassileikettä (100) ja kivennäistä (24). Valkuaistavoite oli $180 \mathrm{~g} / \mathrm{kg}$ ka. Väkirehukioskista saatava väkirehu oli teollista täysrehua (Suomen Rehu Oy).

Taulukko 1. Koeryhmien S ja KS ruokinnat.

\begin{tabular}{|l|l|l|l|}
\hline Rehu & Laktaatiopäivät & S: Seos A & KS: Seos B + kioskiväkirehu \\
\hline Seos A (51\% väkirehua ka:sta) & $1 \rightarrow$ & vapaasti & - \\
Seos B (45\% väkirehua ka:sta) & $1 \rightarrow$ & - & vapaasti \\
Kioskiväkirehu & $1-100$ & - & $6,5 \mathrm{~kg} / \mathrm{pv}(5,5 \mathrm{~kg} / \mathrm{pv}$ ensikot) \\
& $101-150$ & - & $3,0 \mathrm{~kg} / \mathrm{pv}(2,5 \mathrm{~kg} / \mathrm{pv}$ ensikot) \\
& $150 \rightarrow$ & - & - \\
\hline
\end{tabular}

Rehunäytteiden keruu ja analysointi suoritettiin Khalili ym. (2006) mukaan. Koelehmät kuntoluokitettiin tunnutuksen alkaessa, poikimapäivänä tai sitä seuraavana päivänä ja tämän jälkeen kahden viikon välein. Maitomäärä rekisteröitiin jokaiselta lypsykerralta. Maitonäytteet otettiin kahden viikon välein ja niistä määritettiin rasva, valkuainen ja laktoosi. Maidon urea määritettiin vain joka toisen näytteenottokerran näytteistä seitsemältä lehmältä per ruokinta (Khalili ym. 2006). Seosrehujen ja lisäväkirehun syönnit määritettiin eläinkohtaisesti. Säilörehujen ja väkirehujen rehuarvot laskettiin Rehutaulukoissa (MTT 2004) esitettyjen laskentaperusteiden mukaan. Säilörehun syönti-indeksi 
laskettiin Huhtanen ym. (2002) mukaan. Seosrehujen rehuarvot laskettiin eri komponenttien osuuksien ja rehuarvojen perusteella.

Eläinkohtaisesta päivittäisestä tuotos- ja syöntidatasta laskettiin viikkokeskiarvot, joita käytettiin toistohavaintoina analyyseissä. Nämä lehmäkohtaiset viikkohavainnot analysoitiin käyttäen SASin MIXED ohjelmaa. Tulokset analysoitiin kokonaisaineiston $(n=39)$, mutta myös erikseen ensikoiden $(n=15)$ ja useammin poikineiden $(n=24)$ aineistojen pohjalta koko koekaudelta ja jaksoittain koeasetelman mukaisina jaksoina. Koska poikimakerta ei aiheuttanut merkitsevää yhdysvaikutusta esitetään tulokset kaikkien lehmien keskiarvoina. Ruokintojen välisiä eroja testattiin kontrastein ruokintastrategioiden ja ruokintastrategian ja laktaatioviikon yhdysvaikutuksen osalta. Yhdysvaikutus kuvaa ruokintastrategioiden vaikutusta lypsykauden eri vaiheissa eli käyrän muotoa. Koska ruokintastrategian ja laktaatioviikon välinen yhdysvaikutus tuli merkitseväksi vain maidon rasvapitoisuuden kohdalla, merkittiin taulukkoihin merkitsevyydet vain ruokintastrategian osalta.

\section{Tulokset ja tulosten tarkastelu}

Säilörehun käymislaatua kuvaavat parametrit olivat: $\mathrm{pH}$ oli 3,97, sokeri 57, maitohappo 73 ja etikkahappo $22 \mathrm{~g} / \mathrm{kg}$ ka. Säilörehun syönti-indeksi oli 99.1. Koska säilörehu oli hyvälaatuista, ei väkirehun lisääminen kuudella prosenttiyksiköllä paljoa muuttanut seos A:n laskettuja rehuarvoja verrattuna seos B:hen (Taulukko 2).

Taulukko2. Seoksien, kioskiväkirehun ja säilörehun koostumus ja rehuarvot.

\begin{tabular}{|l|c|c|c|c|}
\hline & $\begin{array}{l}\text { Seos A } \mathbf{~ ( 5 1 ~ \% ~} \\
\text { väkirehua ka:ssa) }\end{array}$ & $\begin{array}{l}\text { Seos B (45 \%o } \\
\text { väkirehua ka:ssa) }\end{array}$ & $\begin{array}{l}\text { Kioski- } \\
\text { lisäväkirehu }\end{array}$ & Säilörehu \\
\hline Kuiva-aine, g/kg & $395,9 \pm 34,1$ & $371,7 \pm 31,2$ & $873,7 \pm 5,2$ & $252,2 \pm 26,2$ \\
& & & & \\
\hline Kuiva-aineessa, g/kg & & $168,4 \pm 3,6$ & $196,6 \pm 3,7$ & $148,3 \pm 6,1$ \\
Raakavalkuainen & $170,4 \pm 3,6$ & $46,4 \pm 1,6$ & $59,3 \pm 5,7$ & - \\
Raakarasva & $46,6 \pm 0,6$ & $387,0 \pm 22,6$ & $208,6 \pm 8,6$ & $512,3 \pm 43,9$ \\
NDF & $369,1 \pm 21,1$ & $162,3 \pm 14,1$ & $334,1 \pm 16,3$ & - \\
Tärkkelys & $183,6 \pm 16,7$ & & & \\
& & $1,01 \pm 0,01$ & $1,11 \pm 0,009$ & $0,97 \pm 0,02$ \\
\hline Rehuarvot & $1,02 \pm 0,01$ & $99,6 \pm 1,0$ & $114 \pm 1,0$ & $86 \pm 1,6$ \\
Ry/kg ka & $101,4 \pm 0,9$ & $5 \pm 3,6$ & $14 \pm 2,7$ & $1 \pm 6,3$ \\
OIV, g/kg ka & $4 \pm 3,3$ & & & \\
PVT, g/kg ka & & & & \\
\hline
\end{tabular}

Koekauden keskimääräisissä maito-, EKM-, rasva- ja valkuaistuotoksissa ei ollut ryhmien välillä tilastollisesti merkitsevää eroa (Taulukko 3). Keskimääräinen väkirehukulutus eläintä kohti koekaudella oli S-ryhmällä (2426 kg) ja KS-ryhmällä (2414 kg) melkein sama. Kokeenaikaisiin keskimääräisiin kuiva-aine syönteihin, ravintoaineiden saantiin ja hyväksikäyttöön ei kioskilisällä ollut vaikutusta. Kokeessa mitattu hyvä valkuaisen hyväksikäyttö selittyy osittain säilörehun ihanteellisella (riittävä, muttei liian korkea) valkuaispitoisuudella (148 g / kg ka). Säilörehun valkuaispitoisuus selittää myös molempien ruokintojen maidon ureapitoisuudet.

Sekä ensikoiden että vanhempien lehmien kuntoluokka oli poikiessa yli 3, mutta laski hieman alle 3 ensimmäisten lypsyviikkojen aikana. Kaikkien lehmien kuntoluokka esitetään oheisessa kuviossa, josta nähdään ettei lypsykauden edetessä suuria muutoksia kuntoluokassa tapahtunut eikä ryhmien välillä ollut mitään eroa kunnon kehityksessä. 
Taulukko 3. Koelehmien keskimääräiset tuotokset ja syönnit koekaudella.

\begin{tabular}{|l|c|c|c|c|}
\hline & $\mathbf{S}^{\mathbf{1}}$ & KS $^{\mathbf{2}}$ & $\mathbf{S E M}^{\mathbf{3}}$ & $\begin{array}{l}\text { Tilastollinen } \\
\text { merkitsevyys }(\mathbf{P}<)^{\mathbf{4}}\end{array}$ \\
\hline Tuotos, kg/pv & 31,8 & 32,2 & 1,07 & \\
Maito & 32,9 & 32,9 & 0,97 & \\
EKM & 1,313 & 1,326 & 0,038 & \\
Rasva & 1,073 & 1,081 & 0,028 & \\
Valkuainen & 1,559 & 1,591 & 0,052 & \\
Laktoosi & & & & \\
Maidon pitoisuudet, g/kg & 41,7 & 41,9 & 0,66 & \\
Rasva & 34,2 & 34,1 & 0,45 & \\
Valkuainen & 48,9 & 49,6 & 0,32 & \\
Laktoosi & 22,5 & 22,8 & 1,07 & \\
Urea, mg/100 ml & 21,2 & 20,8 & 0,35 & \\
\hline Syönti, kg ka/pv & 21,5 & 21,2 & 0,36 & \\
Ry/pv & 252 & 249 & 4,2 & \\
ME MJ/pv & 3615 & 3577 & 58,1 & \\
Raakavalkuainen, g/pv & 2142 & 2103 & 35,1 & \\
OIV, g/pv & 105 & 130 & 12,1 & \\
PVT, g/pv & 1,52 & 1,56 & 0,047 & \\
\hline EKM/ry & & & & \\
Maitovalkuainen/ & 0,300 & 0,302 & 0,008 & \\
rehuvalkuainen, g/g & & & & \\
& & & & \\
\hline
\end{tabular}

${ }^{1} \mathrm{~S}=$ seosrehuruokinta, seoksessa $51 \%$ väkirehua kuiva-aineesta laskettuna

${ }^{2} \mathrm{KS}=$ kioski+seosrehuruokinta, seoksessa 45 \% väkirehua kuiva-aineessa ja väkirehuannos vanhemmat/ensikot oli laktaatiopäivinä 1 - 100 6,5/5,5 kg/pv ja 101 - 150 3,0/2,5 kg/pv. Kioskiväkirehua ei annettu kun poikimisesta oli kulunut yli $150 \mathrm{pv}$.

${ }^{3} \mathrm{SEM}=$ keskiarvon keskivirhe.

${ }^{4} \mathrm{P}>0.10$.

\section{Kuntoluokka}

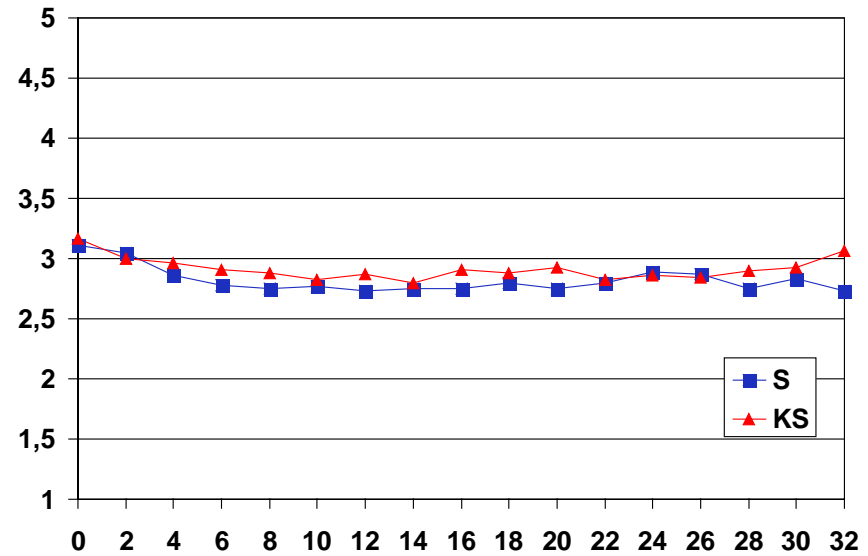

Laktaatioviikko

Kuvio. Kuntoluokka, kaikki lehmät. 
Jaksottaisessa tarkastelussa nähdään, että ensimmäisen 100 päivän aikana KS-ryhmän lehmillä oli korkeammat EKM-tuotokset kuin S-ryhmän lehmillä. Keski- ja loppulypsykaudella olivat tuotokset puolestaan korkeammat S-ryhmän lehmillä, erot eivät olleet kuitenkaan missään lypsykauden vaiheessa merkitseviä (Taulukko 4). Keskimääräinen kioskirehun syönti oli ensikoilla 3.5 kg ka/pv ja vanhemmilla $4.7 \mathrm{~kg} \mathrm{ka} / \mathrm{pv}$ ensimmäisen 100 päivän aikana. Laktaatiopäivinä 101 - 150 olivat syönnit $2.0 \mathrm{~kg} \mathrm{ka} / \mathrm{pv}$ ja $2.5 \mathrm{~kg} \mathrm{ka/pv}$ ensikoilla ja vanhemmilla vastaavasti. Täten ensimmäisen 100 päivän aikana kioskirehun syönti tarjotusta annoksesta oli vanhemmilla $82.7 \%$ ja ensikoilla vain $72.8 \%$. Annosten laskun jälkeen $(101-150$ pv) oli syönti yli $90 \%$ tarjotusta annoksesta sekä ensikoilla että vanhemmilla lehmillä. Toteutuneilla kioskirehusyönneillä nousi KS-ryhmän dieetin väkirehupitoisuus 56.6 \% laktaatiopäivinä 1 - 100 ja oli sama kuin seosryhmällä eli noin 51 \% laktaatiopäivinä 101 150.

Taulukko 4. Koelehmien jaksottaiset tuotokset ja syönnit.

\begin{tabular}{|c|c|c|c|c|}
\hline Laktaatiopäivät & $S^{1}$ & $\mathrm{KS}^{2}$ & SEM $^{3}$ & $\begin{array}{l}\text { Tilastollinen } \\
\text { merkitsevyys }(\mathrm{P}<)^{4}\end{array}$ \\
\hline $\begin{array}{l}0-100 \\
\text { EKM, kg/pv } \\
\text { Maidon rasva, g/kg } \\
\text { Maidon valkuainen, g/kg } \\
\text { Maidon urea, mg/100 ml } \\
\text { Syönti, kg ka/pv } \\
\text { Ry/pv } \\
\text { Raakavalkuainen, g/pv } \\
\text { Kioskirehun syönti, kg ka/pv } \\
\text { Dieetissä väkirehua, \% }\end{array}$ & $\begin{array}{r}34,3 \\
42,5 \\
33,6 \\
21,5 \\
20,4 \\
20,9 \\
3462 \\
- \\
- \\
51,3\end{array}$ & $\begin{array}{c}35,0 \\
40,8 \\
33,8 \\
21,5 \\
20,9 \\
21,6 \\
3612 \\
\\
4,3 \pm 1,5 \\
56,6\end{array}$ & $\begin{array}{c}1,15 \\
0,82 \\
0,47 \\
1,21 \\
0,44 \\
0,46 \\
70,6\end{array}$ & \\
\hline $\begin{array}{l}100-150 \\
\text { EKM, kg/pv } \\
\text { Maidon rasva, g/kg } \\
\text { Maidon valkuainen, g/kg } \\
\text { Maidon urea, mg/100 ml } \\
\text { Syönti, kg ka/pv } \\
\text { Ry/pv } \\
\text { Raakavalkuainen, g/pv } \\
\text { Kioskirehun syönti, kg ka/pv } \\
\text { Dieetissä väkirehu, \% }\end{array}$ & $\begin{array}{c}33,6 \\
40,8 \\
33,9 \\
24,0 \\
22,1 \\
22,5 \\
3788 \\
\\
- \\
51,2\end{array}$ & $\begin{array}{l}33,1 \\
40,8 \\
33,6 \\
23,4 \\
21,1 \\
21,6 \\
3637 \\
\\
2,3 \pm 0,6 \\
51,5\end{array}$ & $\begin{array}{c}0,96 \\
0,96 \\
0,51 \\
1,37 \\
0,42 \\
0,44 \\
75,5\end{array}$ & 0 \\
\hline $\begin{array}{l}150-224 \\
\text { EKM, kg/pv } \\
\text { Maidon rasva, g/kg } \\
\text { Maidon valkuainen, g/kg } \\
\text { Maidon urea, mg/100 ml } \\
\text { Syönti, kg ka/pv } \\
\text { Ry/pv } \\
\text { Raakavalkuainen, g/pv } \\
\text { Dieetissä väkirehua, \% }\end{array}$ & $\begin{array}{c}30,7 \\
41,7 \\
35,6 \\
22,8 \\
21,4 \\
21,7 \\
3778 \\
\\
51,3\end{array}$ & $\begin{array}{c}29,7 \\
43,7 \\
35,3 \\
23,5 \\
20,4 \\
20,5 \\
3459 \\
\\
45,5\end{array}$ & $\begin{array}{c}1,23 \\
1,06 \\
0,60 \\
1,20 \\
0,54 \\
0,55 \\
96,9\end{array}$ & \\
\hline
\end{tabular}

${ }^{1} \mathrm{~S}=$ seosrehuruokinta, seoksessa 51\% väkirehua kuiva-aineesta laskettuna

${ }^{2} \mathrm{KS}=$ kioski+seosrehuruokinta, seoksessa 45 \% väkirehua kuiva-aineessa ja väkirehuannos vanhemmat/ensikot oli laktaatiopäivinä 1 - 100 6,5/5,5 kg/pv ja 101 - 150 3,0/2,5 kg/pv. Kioskiväkirehua ei annettu kun poikimisesta oli kulunut yli $150 \mathrm{pv}$.

${ }^{3} \mathrm{SEM}=$ keskiarvon keskivirhe.

${ }^{4}$ o $\mathrm{P}<0.10$; ei merkitsevä ero $\mathrm{P}>0.10$. 
Ensikoiden kohdalla jaksottaiset tulokset poikkesivat kokoaineiston tuloksista. Ensikoilla KSryhmän tuotokset olivat koko koekauden korkeammat kuin S-ryhmän lehmien tuotokset. Tilastollisesti ero oli lähes merkitsevä $(\mathrm{P}<0.10)$ laktaatiopäivinä $100-150$. Tulokset viittaavat siihen, että ensikot voisivat hyötyä kioski-seosrehuruokinnasta, kun taasen vanhempien lehmien kohdalla ei ruokintastrategialla ollut vaikutusta tuotoksiin.

Tutkimuksen tuloksia voidaan soveltaa myös robottilypsytilalle, jossa on hyvä ruokkia lehmiä laimeammalla seoksella ja antaa väkirehulisä erikseen. Prescott ym. (1998) mukaan väkirehulisä motivoi lehmiä saapumaan lypsyrobotille lypsettäväksi voimakkaammin verrattuna lypsyyn.

\section{Johtopäätökset}

Väkirehun kokonaiskulutuksessa koekaudella ei ruokintastrategioiden välillä ollut eroa. Ruokintastrategioiden välillä ei ollut eroa myöskään kokeenaikaisissa keskimääräisissä tuotoksissa, syönneissä tai kunnon kehityksessä. Kaiken kaikkiaan koetulokset osoittivat, että molemmat ruokintastrategiat soveltuivat hyvin lehmien ruokintaa ja ovat vaihtoehtoja ruokinnan toteuttamissa olosuhteista riippuen.

\section{Kirjallisuus}

Huhtanen, P., Khalili, H., Nousiainen, J.I., Rinne, M., Jaakkola, S., Heikkilä, T. \& Nousiainen, J. 2002. Prediction of the relative intake potential of grass silage by dairy cows. Lives. Prod. Sci. 73: 111-130.

Khalili, H., Mäntysaari, P., Sariola, J. \& Kangasniemi, R. 2006. Effect of a total mixed ration alone versus another total mixed ration with extra concentrate supplement on the performance of dairy cows. Agric. Food Sci. submitted.

MTT. 2004. Rehutaulukot ja ruokintasuositukset [http://www.agronet.fi/rehutaulukot/].

Mäntysaari, P., Nousiainen, J. \& Huhtanen, P. 2003. The effect of constant or variable forage to concentrate ratio in total mixed ration on performance of primiparous dairy cows. Livest. Prod. Sci. 82: 27 - 37.

Mäntysaari, P., Huhtanen, P., Nousiainen, J. \& Virkki, M. 2004. The effect of concentrate crude protein and feeding strategy of total mixed ration on performance of primiparous dairy cows. Livest. Prod. Sci. 85: 223-233. Mäntysaari, P., Huhtanen, P., Nousiainen, J. \& Virkki, M. 2005. The effect of protein-feeding strategy during lactation on performance of primiparous dairy cows fed total mixed ration. Livest. Prod Sci. 94: 189-198.

Prescott, B.B., Mottram, T.T. \& Webster, A.J.F. 1998. Relative motivations of dairy cows to be milked or fed in a Y-maze and an automatic milking system. Appl. Anim. Behav. Sci. 57: 23-33. 